\title{
Efektivitas Penggunaan Media Poster dalam Pembelajaran Keterampilan Berbicara Biografi Pada Siswa Kelas VII SMP Negeri 18 Kota Jambi
}

\author{
Uli Wahyuni ${ }^{1}$ \\ ${ }^{1}$ Dosen FKIP Universitas Batanghari Jambi, Indonesia \\ Correspondance email: Uli09yumna@gmail.com
}

\begin{abstract}
Abstrak: Penelitian ini bertujuan untuk mengetahui: (1) perbedaan prestasi belajar keterampilan berbicara Biografi antara siswa kelas VII SMP Negeri 18 Kota jambi yang diajar dengan menggunakan media poster dengan siswa yang diajar tanpa menggunakan media poster; (2) keefektifan media poster dalam pembelajaran biografi pada keterampilan berbicara kelas VII SMP Negeri 18 Kota Jambi. Penelitian ini merupakan penelitian quasi experiment. Desain penelitian ini adalah pre-test and post test group. Subjek dalam penelitian ini adalah seluruh siswa kelas VII SMP Negeri 18 Kota Jambi. Sampel diambil menggunakan teknik simple random sampling. Kelompok terdiri dari dua kelas yakni F sebagai kelompok eksperimen sebanyak 32 siswa dan D sebagai kelompok kontrol sebanyak 32 siswa. Data penelitian diambil menggunakan tes yakni tes berbicara. Validitas yang digunakan dalam penelitian ini adalah validitas isi dan validitas konstruk. Reliabilitas yang digunakan dalam penelitian ini adalah reliabilitas alpha cronbach. Sedangkan data penelitian ini dianalisis menggunakan uji-t dan gain score. Hasil penelitian ini menghasilkan (1) nilai $t_{\text {hitung }}>t_{\text {tabel }}$ yaitu $2,314>2,011$ dengan $\mathrm{df}=47$ pada taraf signifikansi $5 \%$. Hasil perhitungan tersebut menunjukkan adanaya perbedaan prestasi belajar keterampilan berbicara biografi siswa antara kelas yang diajar menggunakan media poster dan yang diajar tanpa menggunakan media poster; (2) perhitungan nilai rerata gain score, kelas eksperimen mempunyai rerata gain score sebesar 0,303 yang lebih besar daripada rerata gain score kelas kontrol sebesar 0,225. dengan demikian dapat disimpulkan bahwa pembelajaran dengan menggunakan media poster lebih efektif dalam pembelajaran keterampilan berbicara biografi siswa kelas VII SMP Negeri 18 Kota Jambi.
\end{abstract}

Kata Kunci: Efektifitas, Media Poster, Keterampilan Berbicara

\begin{abstract}
This study aims to determine: (1) the differences in learning achievement of speaking skills in Biography between class VII students of SMP Negeri 18 Jambi City who were taught using poster media with students who were taught without using poster media; (2) the effectiveness of poster media in learning biography on speaking skills of class VII SMP Negeri 18 Jambi City. This research is a quasi experimental study. The research design was a pre-test and post test group. The subjects in this study were all grade VII students of SMP Negeri 18 Jambi City. Samples were taken using simple random sampling technique. The group consisted of two classes, namely $F$ as an experimental group of 32 students and D as a control group of 32 students. The research data was taken using a test, namely the speaking test. The validity used in this research is content validity and construct validity. The reliability used in this study was Alpha Cronbach's reliability. While the research data were analyzed using $t$-test and gain score. The results of this study resulted in (1) the value of tcount $>$ ttable, namely 2.314> 2.011 with $\mathrm{df}=47 \mathrm{at}$ the $5 \%$ significance level. The results of these calculations indicate that there is a difference in the learning achievement of students' biographical speaking skills between classes taught using poster media and those taught without using poster media; (2) the calculation of the mean gain score, the experimental class has an average gain score of 0.303 which is greater than the average gain score of the control class of 0.225. Thus it can be concluded that learning using poster media is more effective in learning biographical speaking skills for seventh grade students of SMP Negeri 18 Jambi City.
\end{abstract}

Keywords: Effectiveness, Media Poster, Speaking Skills

\section{PENDAHULUAN}

Pembelajaran bahasa Indonesia merupakan pembelajaran wajib pada semua jenjang pendidikan. Pembelajaran bahasa Indonesia terdiri dari pembelajaran bahasa dan sastra. Pembelajaran bahasa Indonesia bertujuan untuk meningkatkan keterampilan siswa dalam mengomunikasikan bahasa Indonesia secara baik dan benar, serta menumbuhkan apresiasi siswa terhadap sastra Indonesia (Suryaman, 2009:6).

Keterampilan berbahasa setiap individu yang dimiliki sejak lahir akan terus berkembang seiring dengan perkembangan pola pikirnya. Menurut Tarigan (2008: 1) keterampilan berbahasa mempunyai empat komponen, yaitu keterampilan menyimak, berbicara, menulis, membaca. Berdasarkan keempat keterampilan berbahasa tersebut, keterampilan berbicaralah yang menarik perhatian peneliti. Hal itu karena keterampilan berbicara merupakan satusatunya keterampilan komunikasi dua arah dengan bahasa lisan secara langsung. 
Menurut Sudibyo (1997: 34) berbicara adalah keterampilan menyampaikan pesan melalui bahasa lisan. Kaitan antara pesan dan bahasa lisan sebagai media penyampaian sangat erat. Pesan yang diterima oleh pendengar tidaklah dalam wujud asli, tetapi dalam bentuk bunyi bahasa. Selain itu, menurut Tarigan (2008: 16) berbicara adalah kemampuan mengucapkan bunyi-bunyi artikulasi atau kata-kata untuk mengekspresikan, menyatukan atau menyampaikan pikiran, gagasan dan perasaan.

Berbicara adalah salah satu kegiatan transfer informasi dankomunikasi dua arah secara langsung baik dengan bertatap muka maupun tanpa bertatap muka. Berbicara secara langsung dengan bertatap muka antara lain, berbicara untuk melaporkan, berbicara secara kekeluargaan, berbicara untuk meyakinkan dan berbicara untuk merundingkan.

Dalam kehidupan sehari-hari, berbicara sering kali digunakan untuk menceritakan sesuatu, baik untuk menceritakan informasi yang ada dalam televisi, informasi yang ada dalam buku, koran, ataupun majalah, bahkan cerita yang hanya didengar, seperti informasi pada radio. Bercerita seperti itu secara tidak langsung sudah menjadi kebiasaan yang dilakukan setiap orang pada umumnya. Cerita yang dikeluarkan atas dasar dari sumber yang didengar ataupun dibaca. Bercerita terhadap sebuah informasi terkadang menggunakan bahasa yang kurang sopan, kurang etis, bahkan bahasa yang tidak baku itulah yang sering dilontarkan karena semua itu terkadang secara spontan pengucapannya.

Dalam situasi formal sering timbul rasa gugup, sehingga dalam bercerita menjadi tidak teratur dan akhirnya bahasa yang dipakai menjadi tidak teratur pula, seperti dalam praktik di sekolah. Keterampilan berbicara secara formal yang baik dan benar memerlukan latihan, praktik dan pengarahan yang dapat membahasakan pikirannya sendiri, sehingga maksud pembicara dapat dipahami oleh lawan bicara dengan tepat. Keterampilan berbicara dapat dilatih melalui upaya secara formal disekolah. Sesuai dengan silabus bahasa Indonesia Sekolah Menengah Pertama (SMP), Terdapat Kompetensi Inti (KI) yaitu berbicara yang dikhususkan mengenai berbicara untuk mengungkapkan pikiran, perasaan, informasi, dan pengalaman melalui kegiatan menaggapi cerita dan telepon yang mempunyai kompetensi dasar (KD) yaitu menceritakan tokoh idola dengan mengemukakan identitas tokoh, keunggulan, dan alasan mengidolakannya dengan pilihan kata yang sesuai. Indikator dalam kurikulum ini adalah mampu mengemukakan identitas tokoh, mampu menentukan keunggulan tokoh dengan argumen yang tepat, mampu menceritakan tokoh dengan pedoman kelengkapan identitas tokoh.

Proses kegiatan bercerita biasanya dapat menunjukkan usaha siswa untuk menyampaikan kembali cerita yang telah didengarnya atau dibacanya dan memperhatikan usaha dan cara siswa menjawab pertanyaan yang diajukan setelah pembacaan cerita. Pada saat siswa menyampaikan cerita, guru dapat memperbaiki susunan ide, cara penyampaian, mengetahui kemampuan siswa dalam menangkap isi cerita dan dapat pula digunakan untuk memperbaiki bahasa dan gaya bahasanya. Apabila siswa mengalami kesulitan saat bercerita di depan kelas, guru dapat memberikan nasihat-nasihat dan mendorong siswa agar berani tampil di depan kelas.

Pembelajaran bahasa Indonesia di sekolah terbagi menjadi dua, yaitu pembelajaran bahasa dan pembelajaran sastra. Di Indonesia beberapa tahun terakhir sudah menerapkan kurikulum 2013 yakni kurikulum yang dikembangkan dengan tujuan mewujudkan tujuan pendidikan nasional. Pada proses pembelajarannya guru ditempatkan sebagai fasilitator sedangkan murid menjadi yang berperan aktif atau mandiri. Tahun pelajaran 2017-2019 di beberapa sekolah telah menerapkan Kurikulum 2013 revisi 2017. Pada jenjang SMP kelas VII semester genap, materi yang didapat diantaranya adalah teks literasi, surat pribadi/surat dinas, puisi rakyat, dan fabel. Pembelajaran memiliki tujuh komponen yang harus dipenuhi diantaranya kurikulum, guru, siswa, metode, materi, media, dan evaluasi.

Selain itu, untuk mendapatkan hasil yang optimal dalam menyampaikan materi pelajaran, guru harus mampu menjalin hubungan yang harmonis dengan siswa sehingga terjalin komunikasi dua arah. Sikap otoriter gurupun harus dihindari agar siswa lebih terbuka dan tidak takut untuk menunjukkan kemampuannya. Mata pelajaran Bahasa Indonesia dalam Kurikulum 2013 cenderung berbasis teks. Seperti teks cerita moral/fabel, ulasan, diskusi, cerita prosedur, dan cerita biografi. Dalam kompetensi dasarnya menunjukkan bahwa peserta didik diwajibkan untuk dapat menyusun jenis-jenis teks. Artinya bahwa siswa diwajibkan untuk menguasai keterampilan menulis dan berbicara. Salah satu fokus dalam penelitian eksperimen ini ialah mengenai ketrampilan berbicara siswa dalam menyusun teks Biografi dengan media poster biografi. Berdasarkan Kurikulum 2013 revisi 2017 teks cerita moral/fabel merupakan salah satu materi yang terdapat pada jenjang SMP/MTs kelas VII dengan KD 3.16 Menelaah struktur dan kebahasaan fabel/legenda daerah setempat yang dibaca dan didengar.

Selain menjalin hubungan yang harmonis dengan siswa, guru juga dapat menggunakan media tertentu dalam proses pembelajaran. Menurut Arsyad (2002: 3) media pembelajaran diartikan sebagai alat-alat grafis, photografis, atau elektronis untuk menangkap, memproses, dan menyusun kembali informasi visual atau verbal. Dalam pembelajaran bahasa, suatu media dapat bersifat komunikatif, dan dapat juga tidak bersifat komunikatif. Media pembelajaran merupakan alat atau sarana dapat memperlancar proses belajar mengajar. Media berfungsi sebagai alat penyalur komunikasi yang dapat menunjang pembelajaran yang dilaksanakan antara guru dan siswa.

Media pembelajaran membuat kegiatan belajar mengajar lebih bervariasi. Media yang digunakan sangat variatif salah satunya adalah biografi. Biografi adalah buku yang berisi riwayat hidup seseorang, tentu saja tidak 
semua aspek kehidupan dan peristiwa dikisahkan, melainkan dibatasi pada hal-hal tertentu yang dipandang perlu dan menarik untuk diketahui orang lain, atau pada hal-hal tertentu yang mempunyai nilai jual (Nurgiyantoro, 2005: 29). Selain itu, dengan menggunakan biografi dalam pembelajaran berbicara mampu membantu siswa untuk siap berbicara, bercerita, yang berhubungan dengan kisah dalam isi teks biografi, dapat melatih siswa berfikir dengan cepat dan tersusun logis, melatih siswa untuk berbicara dengan bahasa yang tepat.

Media Poster lebih lengkap dan tersusun dalam mengisahkan riwayat hidup seseorang. Berdasarkan dari hasil wawancara dengan salah satu guru yg bernama yuli, mengatakan bahwa SMP Negeri 18 Kota Jambi belum menerapkan media pembelajaran yang tepat dalam pembelajaran berbicara menceritakan tokoh idola. Penerapan media poster ini, diharapkan proses pembelajaran berbicara menceritakan tokoh idola menjadi lebih efektif. Akan tetapi, keefektifan penggunaan media poster biografi dalam pembelajaran berbicara menceritakan tokoh idola masih harus diuji melalui penelitian. Penelitian dilakukan di SMP Negeri 18 Kota Jambi. Peneliti memlilih SMP Negeri Kota jambi sebagai lokasi penelitian karena Media Poster belum pernah diujicobakan di sekolah ini. Berdasarkan latar belakang diatas, perlu kiranya dilakukan penelitian dengan judul "Efektivitas Penggunaan Media Poster dalam Pembelajaran Keterampilan Berbicara Biografi pada Siswa Kelas VII SMP Negeri 18 Kota Jambi"

\section{METODE PENELITIAN}

Penelitian ini merupakan penelitian kuantitatif dengan jenis penelitian quasi eksperiment. Quasi Eksperiment sering disebut sebagai eksperimen tidak sebenarnya atau eksperimen pura-pura atau biasa disebut pre experimental design. Disebut demikian karena eksperimen jenis ini belum memenuhi persyaratan seperti cara eksperimen yang dapat dikatakan ilmiah mengikuti peraturan-peraturan tertentu (Arikunto 2013: 123). Hasil yang diharapkan dapat diketahui antara efektivitas Penggunaan Media Poster dalam Pembelajaran Keterampilan Berbicara Biografi pada Siswa Kelas VII SMP Negeri 18 Kota Jambi

\section{HASIL DAN PEMBAHASAN}

Deskripsi Kondisi Awal Keterampilan Berbicara Kelompok Kontrol dan Kelompok Eksperimen Pada kondisi awal keterampilan bericara biografi kelompok kontrol dan kelompok eksperimen dapat diketahui melalui adanya pretest. Pre-test ini dilakukan pada saat awal penelitian atau pada saat sebelum para siswa diberikan perlakuan. Soal pretest antara kelas kontrol dan kelas eksperimen tidak ada perbedaan atau sama. Soal yang diberikan tersebut sebelumnya sudah divalidasi oleh dua expert judgement serta telah dinyatakan reliabel.

Kemudian pre-test dinilai berdasarkan kriteria penilaian menurut Échelle de Haris Tagliante. Setelah data nilai pre-test diperoleh, maka akan diketahui data nilai dari kelas kontrol dan kelas eksperimen. Untuk kelompok kontrol memperoleh skor tertinggi 22 dan skor terendah 13. Rata-rata skor pre-test 16,75; dengan median 17,00; modus18 dan standar deviasi 1,867. Sedangkan untuk kelompok eksperimen memperoleh skor tertinggi 19 dan skor terendah 13. Rata-rata skor pre-test 16,09; dengan median 16,00; modus 16 dan standar deviasi 1,445.

Deskripsi Kondisi Akhir Keterampilan Berbicara Kelompok Kontrol dan Kelompok Eksperimen Setelah diberikan perlakuan menggunakan media papan selip pada kelompok eksperimen dan pemberian materi tanpa menggunakan media poster pada kelompok kontrol, selanjutnya para siswa diberikan post-test yang bertujuan untuk mengetahui kondisi akhir keterampilan berbicara Biografipada kelompok kontrol dan kelompok eksperimen.

Pemberian perlakuan dengan menggunakan media poster pada kelompok eksperimen menghasilkan perbedaan antara hasil post-test kelompok kontrol dan kelompok eksperimen. Setelah dilakukan analisis dengan menggunakan uji-t sampel bebas pada post-test menunjukkan bahwa terdapat perbedaan yang signifikan terhadap kelompok eksperimen yang diberikan perlakuan menggunakan media poster dengan kelompok kontrol yang tidak diberi perlakuan menggunakan media poster.

Berdasarkan hasil post-test dapat diketahui bahwa skor rata-rata kelompok eksperimen lebih tinggi dari kelompok kontrol yaitu 18,91 > 17,97. Hasil post-test kelompok kontrol memperoleh skor tertinggi 20 dan skor terendah 15. Rata-rata skor post-test 17,97; dengan median 18,00; modus 19 dan standar deviasi 1,379. Sedangkan untuk kelompok eksperimen memperoleh skor tertinggi 23 dan skor terendah 16. Rata-rata skor post-test 18,91; dengan median 19,00; modus 19 dan standar deviasi 1,653.

\section{Hasil Uji Coba}

Hasil uji coba instrument dilakukan di kelas VII A sebanyak 32 siswa. Uji reliabilitas dalam penelitian ini menggunakan reliabilitas Alpha Cronbach dengan bantuan SPSS 20 for windows. Suatu alat ukur yang reliabel adalah alat ukur yang mempunyai tingkat reliabilitas yang tinggi. Reliabilitas suatu tes pada umumnya diekspresikan secara numeric dalam bentuk koefisien. Koefisien tinggi menunjukkan reliabilitas tinggi dan sebaliknya, jika suatu tes rendah maka reliabilitas tes rendah. Apabila suatu tes mempunyai reliabilitas sempurna berarti tes tersebut mempunyai koefisien 1 atau -1 (Sukardi, 2010: 128). Dari hasil uji coba didapatkan nilai reliabilitas sebesar 0,731. Dari hasil 
tersebut dapat disimpulkan bahwa instrument tersebut dapat dikatakan reliabel. Lebih lengkapnya tabel perhitungan reliabilitas uji coba dapat dilihat pada lampiran reliabilitas.

\section{Uji Prasyarat Analisis Data}

Sebelum melakukan analisis data, terlebih dahulu dilakukan uji prasyarat analisis. Prasyarat yang harus dipenuhi adalah uji normalitas sebaran data dan uji homogenitas variansi.

\section{Uji Normalitas Sebaran}

Uji normalitas sebaran digunakan untuk mengetahui apakah data yang terdapat dalam penelitian tersebut berdistribusi normal atau tidak. Dalam hal ini, uji normalitas sebaran menggunakan program SPSS 20.0 for windows. Uji normalitas diujikan pada masing-masing variable penelitian yaitu pre-test dan post-test kelas eksperimen dan kelas control. Data dikatakan berdistribusi normal apabila nilai taraf signifikansi hitung lebih besar dari taraf signifikansi $5 \%(0,05)$.

Hasil uji normalitas variabel penelitian disajikan dalam tabel berikut.

Tabel 1. Hasil Uji Normalitas

\begin{tabular}{lllll}
\hline No & Kelas & N & P & Keterangan \\
\hline 1. & Pre-test kelas kontrol & 32 & 0,494 & \\
\hline 2. & Post-test kelas kontrol & 32 & 0,118 & P $>0,05$ \\
\hline 3. & Pre-test kelas eksperimen & 32 & 0,185
\end{tabular}

\begin{tabular}{llll}
\hline 4. & Post-test kelas eksperimen & 32 & 0,349 \\
\hline
\end{tabular}

Dari hasil uji normalitas variabel penelitian dapat diketahui variabel pre-test da post-test kelas kontrol dan kelas eksperimen nilai signifikansinya lebih besar dari 0,05 sehingga dapat disimpulkan bahwa semua variabel pre-test dan post-test kelas kontrol maupun kelas eksperimen adalah distribusi normal.

\section{Uji Homogenitas Variansi}

Uji homogenitas dimaksudkan untuk mengetahui homogenitas tidaknya variansi sampel yang diambil dari suatu populasi. Variansi dikatakan homogen apabila nilai $\mathrm{F}_{\text {hitung }}<\mathrm{F}_{\text {tabel }}$ pada taraf signifikansi 5\%. Hasil perhitungan uji homogenitas data dilakukan dengan bantuan SPSS 20.0 for windows. Jika $\mathrm{F}_{\text {hitung }}<\mathrm{F}_{\text {tabel }}$ maka data kelompok tersebut dikatakan homogen.

Dari hasil pengujian statistik diperoleh nilai $\mathrm{F}_{\text {hitung }}$ pre-test kedua kelas sebesar 2,202 dan dilihat pada $\mathrm{F}_{\text {tabel }}$ sebesar 3,996 selain itu nilai signifikansi pre-test kedua kelas sebesar 0,143. Dengan demikian data kedua kelompok tersebut dapat dikatakan homogeny karena ditemukan bahwa $\mathrm{F}_{\text {hitung }}<\mathrm{F}_{\text {tabel }}$ dan nilai

signifikansi data lebih besar dari 0,05. Perhitungan selengkapnya dapat dilihat pada lampiran uji homogenitas.

\section{Deskripsi Data Penelitian}

1. Data Penelitian

Dari hasil proses pembelajaran dengan menggunakan media poster dalam pembelajaran keterampilan berbicara Biografiakan diuraikan data-data yang diperoleh setelah pelaksanaan penelitian yaitu melalui pre-test, treatment dan post-test pada siswa kelas VII F dan D SMP Negeri 18 Kota Jambi. Berikut ini adalah hasil analisis data yang terkumpul:

2. Data Tes Awal (Pre-test)

Data Pre-test Kelas Kontrol

Dalam penelitian ini, kelas kontrol merupakan kelas yang diajar tanpa menggunakan media poster. Sebelum diberi perlakuan kepada siswa kelas kontrol, terlebih dahulu dilakukan pre-test untuk mengukur kemampuan awal siswa. Subjek kelas kontrol sebanyak 32 siswa. Berikut hasil data pre-test kelas kontrol dapat dilihat pada tabel dibawah ini.

Tabel 2. Data pre-test kelas kontrol

\begin{tabular}{clc}
\hline No & \multicolumn{1}{c}{ Data pre-test kelas control } & Skor \\
\hline 1 & Skor tertinggi (Skor Max) & 22 \\
\hline 2 & Skor terendah (Skor Min) & 13 \\
\hline 3 & Mean & 16,75 \\
\hline 4 & Median & 17,00 \\
\hline 5 & Modus & 18 \\
\hline 6 & Standar Deviasi & 1,867 \\
\hline
\end{tabular}


Berdasarkan tabel diatas hasil deskriptif dari hasil pre-test kelas kontrol dengan skor tertinggi $=22$; skor minimum $=13 ;$ mean $=16,75 ;$ median $=17,00 ;$ modus $=18 ;$ standar deviasi $=1,867$. Selanjutnya adalah pembuatan tabel distribusi frekuensi yang dilakukan dengan menentukan rentang kelas, banyak kelas dan panjang kelas sebagai berikut.

$$
\begin{aligned}
\text { Rentang kelas }= & X_{\max }-X_{\min } \\
& =22-13 \\
& =9=5,68 \text { (dibulatkan menjadi } 6) \\
\text { Panjang kelas } & =\text { rentang kelas/ banyak kelas } 9 / 6=1,5
\end{aligned}
$$

Hasil perhitungan menunjukkan bahwa distribusi skor pre-test yang diperoleh dengan rentang kelas adalah 9, banyak kelas adalah 6 dan panjang kelas adalah 1,5 sehingga dapat disusun pada tabel dibawah ini.

Tabel 3. Frekuensi Skor Pre-test Keterampilan Berbicara Kelas Kontrol

\begin{tabular}{ccccc}
\hline No & Interval Kelas & Frekuensi & Frekuensi Relatif & Frekuensi Komulatif \\
\hline 1. & $13-14,50$ & 3 & $9,38 \%$ & $9,38 \%$ \\
\hline 2. & $14,51-16,00$ & 10 & $31,25 \%$ & $40,63 \%$ \\
\hline 3. & $16,01-17,50$ & 7 & $21,88 \%$ & $62,50 \%$ \\
\hline 4. & $17,51-19,00$ & 8 & $25 \%$ & $87,5 \%$ \\
\hline 5. & $19,01-20,50$ & 3 & $9,37 \%$ & $96,87 \%$ \\
\hline 6. & $20,51-22,00$ & 1 & $3,13 \%$ & $100 \%$ \\
\hline & Total & 32 & $100 \%$ & \\
\hline
\end{tabular}

Berdasarkan tabel 13 dan gambar 3, terlihat bahwa siswa yang mempunyai skor keterampilan berbicara Biografiterbanyak ditunjukkan pada interval 14,51 - 16,00 dengan frekuensi 10 siswa atau sebanyak 31,25\% siswa. Sedangkan siswa yang mempunyai skor keterampilan berbicara Biografi paling sedikit ditunjukkan pada interval 20,51 - 22,00 dengan frekuensi sebanyak 1 siswa atau 3,13\% siswa.

Data Pre-test Kelas Eksperimen

Dalam penelitian ini, kelas eksperimen merupakan kelas yang mendapat perlakuan berupa penggunaan media poster. Pada kelas eksperimen juga dilakukan tindakan pre-test sama seperti kelas kontrol untuk mengukur kemampuan awal siswa. Subjek kelas eksperimen sebanyak 32 siswa.

Berikut hasil data pre-test kelas eksperimen dapat dilihat pada tabel dibawah ini.

Tabel 4. Data pre-test kelas eksperimen

\begin{tabular}{cll}
\hline No & Data Pre-Test Kelas Eksperimen & Skor \\
\hline 1 & Skor tertinggi (Skor Max) & 19 \\
\hline 2 & Skor terendah (Skor Min) & 13 \\
\hline 3 & Mean & 16,09 \\
\hline 4 & Median & 16,00 \\
\hline 5 & Modus & 16 \\
\hline 6 & Standar Deviasi & 1,445 \\
\hline
\end{tabular}

Berdasarkan tabel diatas hasil deskriptif dari hasil pre-test kelas kontrol dengan skor tertinggi $=19$; skor minimum $=13$; mean $=16,09 ;$ median $=16,00 ;$ modus $=16 ;$ standar deviasi $=1,445$.

Selanjutnya adalah pembuatan tabel distribusi frekuensi yang dilakukan dengan menentukan rentang kelas, banyak kelas dan panjang kelas sebagai berikut.

$$
\begin{aligned}
& \text { Rentang kelas }=X_{\max }-X_{\min } \\
& =19-13 \\
& =6 \\
& =5,69 \text { (dibulatkan menjadi 6) }
\end{aligned}
$$

Panjang kelas $=$ rentang kelas/ banyak kelas

$$
=6 / 6=1
$$

Hasil perhitungan menunjukkan bahwa distribusi skor pre-test yang diperoleh dengan rentang kelas adalah 6, banyak kelas adalah 6 dan panjang kelas adalah 1 sehingga dapat disusun pada tabel dibawah ini.

Tabel 5. Frekuensi Skor Pre-test Keterampilan Berbicara Kelas Eksperimen

\begin{tabular}{ccccc}
\hline No & Interval Kelas & Frekuensi & Frekuensi Relatif & Frekuensi Komulatif \\
\hline 1. & $13,00-14,00$ & 6 & $18.75 \%$ & $18,75 \%$ \\
\hline 2. & $14,01-15,00$ & 3 & $9,38 \%$ & $28,13 \%$ \\
\hline 3. & $15,01-16,00$ & 10 & $31,25 \%$ & $59,38 \%$ \\
\hline 4. & $16,01-17,00$ & 8 & $25,00 \%$ & $84,38 \%$ \\
\hline 5. & $17,01-18,00$ & 4 & $12,50 \%$ & $96,88 \%$ \\
\hline 6. & $18,01-19,00$ & 1 & $3,13 \%$ & $100 \%$ \\
\hline & Total & 32 & $100 \%$ & \\
\hline
\end{tabular}


Berdasarkan tabel 15 , terlihat bahwa siswa yang mempunyai skor keterampilan berbicara Biografi terbanyak ditunjukkan pada interval 15,01 - 16,00 dengan frekuensi 10 siswa atau sebanyak 31,25\% siswa. Sedangkan siswa yang mempunyai skor keterampilan berbicara Biografipaling sedikit ditunjukkan pada interval 18,01 - 19,00 dengan frekuensi sebanyak 1 siswa atau 3,13\% siswa.

Data Tes Akhir (Post-test)

Data Post-test Kelas Kontrol

Pada penelitian ini, post-test dilakukan setelah diberikan perlakuan (treatment) yang berbeda antara kelas kontrol dan kelas eksperimen. Post-test dilakukan untuk mengetahui kemampuan akhir pada keterampilan berbicara biografi. Subjek siswa kelas kontrol yaitu kelas VII D yang berjumlah 32 siswa. Berikut hasil data post-test kelas kontrol dapat dilihat pada tabel dibawah ini.

Tabel 6. Data post-test kelas kontrol

\begin{tabular}{cll}
\hline No & Data pre-test kelas kontrol & \multicolumn{1}{c}{ Skor } \\
\hline 1 & Skor tertinggi (Skor Max) & 20 \\
\hline 2 & Skor terendah (Skor Min) & 15 \\
\hline 3 & Mean & 17,97 \\
\hline 4 & Median & 18,00 \\
\hline 5 & Modus & 19 \\
\hline 6 & Standar Deviasi & 1,379 \\
\hline
\end{tabular}

Berdasarkan tabel diatas hasil deskriptif dari hasil post-test kelas kontrol dengan skor tertinggi $=20$; skor minimum $=15 ;$ mean $=17,97 ;$ median $=18,00 ;$ modus $=19 ;$ standar deviasi $=1,379$. Selanjutnya adalah pembuatan tabel distribusi frekuensi yang dilakukan dengan menentukan rentang kelas, banyak kelas dan panjang kelas sebagai berikut.

$$
\begin{aligned}
\text { Rentang kelas }= & X_{\max }-X_{\min } \\
& =20-15 \\
& =5 \\
& =6,03 \text { (dibulatkan menjadi 6) } \\
\text { Panjang kelas }= & \text { rentang kelas/ banyak kelas } \\
& =5 / 6 \\
& =0,83
\end{aligned}
$$

Hasil perhitungan menunjukkan bahwa distribusi skor pre-test yang diperoleh dengan rentang kelas adalah 5, banyak kelas adalah 6 dan panjang kelas adalah 0,83 sehingga dapat disusun pada tabel dibawah ini.

Tabel 7. Frekuensi Skor Post-test Keterampilan Berbicara Kelas Kontrol

\begin{tabular}{cclll}
\hline No & Interval Kelas & Frekuensi & Frekuensi Relatif & Frekuensi Komulatif \\
\hline 1. & $15-15,83$ & 1 & $3,13 \%$ & $3,13 \%$ \\
\hline 2. & $15,84-16,67$ & 4 & $12,50 \%$ & $15,63 \%$ \\
\hline 3. & $16,68-17,50$ & 8 & $25,00 \%$ & $40,63 \%$ \\
\hline 4. & $17,51-18,33$ & 5 & $15,63 \%$ & $56,25 \%$ \\
\hline 5. & $18,34-19,17$ & 10 & $31,25 \%$ & $87,50 \%$ \\
\hline 6. & $19,18-20,00$ & 4 & $12,50 \%$ & $100 \%$ \\
\hline & Total & 32 & $100 \%$ & \\
\hline
\end{tabular}

Berdasarkan tabel 17 dan gambar 5, terlihat bahwa siswa yang mempunyai skor keterampilan berbicara Biografiterbanyak ditunjukkan pada interval 18,34 - 19,17 dengan frekuensi 10 siswa atau sebanyak 31,25\% siswa. Sedangkan siswa yang mempunyai skor keterampilan berbicara Biografipaling sedikit ditunjukkan pada interval 15 15,83 dengan frekuensi sebanyak 1 siswa atau 3,13\% siswa.

Data Post-test Kelas Eksperimen

Pada penelitian ini, post-test dilakukan setelah diberikan perlakuan (treatment) yang berbeda antara kelas kontrol dan kelas eksperimen. Post-test dilakukan untuk mengetahui kemampuan akhir pada keterampilan berbicara Biografisiswa kelas eksperimen yaitu kelas VII F setelah mendapat perlakuan berupa penggunaan media poster. Subjek siswa kelas eksperimen yaitu kelas VII F yang berjumlah 32 siswa. Berikut hasil data post-test kelas eksperimen dapat dilihat pada tabel dibawah ini. 
Tabel 8. Data post-test kelas eksperimen

\begin{tabular}{cll}
\hline No & Data pre-test kelas eksperimen & Skor \\
\hline 1 & Skor tertinggi (Skor Max) & 23 \\
\hline 2 & Skor terendah (Skor Min) & 16 \\
\hline 3 & Mean & 18,91 \\
\hline 4 & Median & 19,00 \\
\hline 5 & Modus & 19 \\
\hline 6 & Standar Deviasi & 1,653 \\
\hline
\end{tabular}

Berdasarkan tabel diatas hasil deskriptif dari hasil post-test kelas eksperimen dengan skor tertinggi = 23; skor minimum $=16 ;$ mean $=18,91 ;$ median $=19,00 ;$ modus $=19 ;$ standar deviasi $=1,653$. Selanjutnya adalah pembuatan tabel distribusi frekuensi yang dilakukan dengan menentukan rentang kelas, banyak kelas dan panjang kelas sebagai berikut.

$$
\begin{aligned}
\text { Rentang kelas }= & X_{\max }-X_{\min } \\
& =23-16 \\
& =7 \\
\text { Banyak kelas } & =1+3,3 \log \mathrm{n} \\
& 5,68(\text { dibulatkan menjadi 6) } \\
\text { Panjang kelas }= & \text { rentang kelas/ banyak kelas } \\
& =7 / 6 \\
& =1,17
\end{aligned}
$$

Hasil perhitungan menunjukkan bahwa distribusi skor pre-test yang diperoleh dengan rentang kelas adalah 7, banyak kelas adalah 6 dan panjang kelas adalah 1,17 sehingga dapat disusun pada tabel dibawah ini.

Tabel 9. Frekuensi Skor Pre-test Keterampilan Berbicara Kelas Eksperimen

\begin{tabular}{cclll}
\hline No & Interval Kelas & Frekuensi & Frekuensi Relatif & Frekuensi Komulatif \\
\hline 1. & $16-17,17$ & 8 & $25,00 \%$ & $25,00 \%$ \\
\hline 2. & $17,18-18,33$ & 4 & $12,50 \%$ & $37,50 \%$ \\
\hline 3. & $18,34-19,50$ & 10 & $31,25 \%$ & $68,75 \%$ \\
\hline 4. & $19,51-20,67$ & 6 & $18,75 \%$ & $87,50 \%$ \\
\hline 5. & $20,68-21,83$ & 1 & $3,13 \%$ & $90.63 \%$ \\
\hline 6. & $21,84-23,00$ & 3 & $9,38 \%$ & $100 \%$ \\
\hline & Total & 32 & $100 \%$ & \\
\hline
\end{tabular}

Berdasarkan tabel 19, terlihat bahwa siswa yang mempunyai skor keterampilan berbicara Biografi terbanyak ditunjukkan pada interval 18,34 - 19,50 dengan frekuensi 10 siswa atau sebanyak 31,25\% siswa. Sedangkan siswa yang mempunyai skor keterampilan berbicara Biografi paling sedikit ditunjukkan pada interval 20,68 - 21,83 dengan frekuensi sebanyak 1 siswa atau 3,13\% siswa.

\section{Hasil Uji-t Post-test Kelas Kontrol dan Kelas Eksperimen}

Teknik analisis ini bertujuan untuk mengetahui perbedaan prestasi belajar keterampilan berbicara Biografipada tahap akhir. Hasil perhitungan uji-t post-test kelas kontrol dan kelas eksperimen menggunakan bantuan komputer program SPSS 20 for windows.

Ringkasan hasil perhitungan uji-t post-test kelas kontrol dan kelas eksperimen tercantum pada tabel dibawah ini.

Tabel 10. Uji-t Post-test Kelas Kontrol dan Kelas Eksperimen

\begin{tabular}{lccccc}
\hline Eksperimen- Kontrol & Df & Table & Thitung & P & Keterangan \\
\hline Post-test & 62 & 1,999 & 2,463 & 0,017 & $\begin{array}{l}\text { thitung }>\text { ttabel } \\
\text { (signifikan) }\end{array}$ \\
\hline
\end{tabular}

Dari hasil uji-t dapat diketahui nilai $t_{\text {hitung }}$ sebesar 2,463 dengan df 62 yang dikonsultasikan dengan taraf signifikansi 5\%. Nilai tersebut kemudian dibandingkan dengan $t_{\text {tabel }}$ sebesar 1,999. Maka dari hasil tersebut diperoleh simpulan bahwa $t_{\text {hitung }}>\mathrm{t}_{\text {tabel. }}$. Hal tersebut menunjukkan bahwa terdapat perbedaan post-test kelas kontrol dan kelas eksperimen. Selain itu, nilai p-value statistic uji-t sebesar $0,017(<0,05)$ yang berarti terdapat perbedaan post-test antara kelas kontrol dan kelas eksperimen. Dengan demikian, dapat disimpulkan bahwa kelas yang mendapat perlakuan dengan menggunakan media poster lebih baik dibandingkan dengan kelas yang mendapat perlakuan tidak menggunakan media poster.

\section{Hasil Perhitungan Gain Score}


Untuk mengetahui apakah media poster lebih efektif dalam pembelajaran keterampilan berbicara Biografisiswa kelas VII dibandingkan dengan siswa kelas VII yang diajar tanpa menggunakan media poster dapat diketahui dengan melihat nilai gain score.

Berikut ini adalah data dari hasil perhitungan gain score kelompok kontrol dan kelompok eksperimen.

Tabel 11. Hasil Perhitungan Gain Score

\begin{tabular}{lcccccc}
\hline $\begin{array}{l}\text { Eksperimen- } \\
\text { Kontrol }\end{array}$ & Df & ttabel & t-hitung & P & Keterangan \\
\hline $\begin{array}{l}\text { Post-test } \\
\text { n }\end{array}$ & 62 & 1,999 & 2,463 & 0,017 & $\begin{array}{l}\text { thitung>ttabel } \\
\text { (signifikan) }\end{array}$ \\
\hline
\end{tabular}

Dari hasil perhitungan gain score kelas kontrol diperoleh nilai sebesar 0,147 dan kelas eksperimen sebesar 0,316 . Hal tersebut berarti bahwa gain score kelas eksperimen lebih besar di bandingkan kelas kontrol. Tingkat perolehan gain score dikategorikan dalam tiga kategori yaitu: $0,7 \leq(<\mathrm{g}>)$ berarti nilai tersebut masuk dalam kategori tinggi ; $0,3 \leq(<\mathrm{g}>)<0,7$ berarti nilai tersebut masuk dalam kategori sedang; dan $(<\mathrm{g}>)<0,3$ berarti nilai tersebut masuk dalam kategori rendah.

Nilai gain score kelas kontrol sebesar 0,147 yang diartikan masuk dalam kategori rendah. Sedangkan nilai gain score kelas eksperimen sebesar 0,316 yang diartikan masuk dalam kategori sedang. Dari hasil tersebut dapat disimpulkan bahwa penggunaan media poster lebih efektif untuk pembelajaran keterampilan berbicara Biografi siswa kelas VII SMP Negeri 18 Kota Jambi dibandingkan dengan siswa kelas VII D yang diajar tanpa menggunakan media poster.

\section{Pengajuan Hipotesis \\ Pengajuan Hipotesis I}

Pada pengajuan hipotesis I, Hipotesis alternative $\left(\mathrm{H}_{\mathrm{a}}\right)$ yang diajukan dalam penelitian ini adalah terdapat perbedaan prestasi belajar keterampilan berbicara Biografiantara siswa kelas VII SMP Negeri 18 Kota Jambiyang diajarkan dengan menggunakan media poster dengan siswa yang diajar tanpa menggunakan media poster. Sedangkan Hipotesis nol $\left(\mathrm{H}_{\mathrm{o}}\right)$ berbunyi tidak terdapat perbedaan prestasi belajar keterampilan berbicara Biografiantara siswa kelas VII SMP Negeri 18 Kota Jambiyang diajarkan dengan menggunakan media poster dengan siswa yang diajar tanpa menggunakan media poster.

Hasil pengolahan data uji-t kelompok dikonsultasikan dengan $t_{\text {tabel }}$ pada taraf signifikansi $5 \%$. Apabila harga $\mathrm{t}_{\text {hitung }}$ lebih besar daripada tabel pada taraf signifikansi $5 \%$ maka $\mathrm{H}_{\mathrm{o}}$ ditolak dan $\mathrm{H}_{\mathrm{a}}$ diterima.

\section{Tabel 12. Uji-t Post-test Kelas Kontrol dan Kelas Eksperimen}

Dari hasil diperoleh perhitungan t hitung sebesar 2,463 dikonsultasikan dengan taraf signifikansi 5\% dan df 62 serta $t_{\text {tabel }}$ sebesar 1,999 ternyata $t_{\text {hitung }}$ lebih besar dari $t_{\text {tabel }}(2,463>1,999)$ sehingga $H_{o}$ yang berbunyi tidak terdapat perbedaan prestasi belajar keterampilan berbicara Biografiantara siswa kelas VII SMP Negeri 18 Kota Jambi yang diajarkan dengan media poster dengan siswa yang diajar tanpa menggunakan media poster berhasil ditolak. Sehingga, $\mathrm{H}_{\mathrm{a}}$ yang berbunyi terdapat perbedaan prestasi belajar keterampilan berbicara Biografi antara siswa kelas VII SMP Negeri 18 Kota Jambi yang diajarkan dengan menggunakan media poster dengan siswa yang diajarkan tanpa menggunakan media poster dapat diterima.

\section{Pengajuan Hipotesis II}

Pada pengujian hipotesis II, Hipotesis alternatif $\left(\mathrm{H}_{\mathrm{a}}\right)$ yang diajukan dalam penelitian ini adalah penggunaan media poster lebih efektif untuk pembelajaran keterampilan berbicara Biografisiswa kelas VII SMP Negeri 18 Kota Jambi yang diajarkan dengan menggunakan media poster dibandingkan dengan siswa kelas VII yang diajarkan tanpa menggunakan media poster. Sedangkan Hipotesis nol $\left(\mathrm{H}_{\mathrm{o}}\right)$ adalah penggunaan media poster sama efektifnya untuk pembelajaran keterampilan berbicara Biografisiswa kelas VII SMP Negeri 18 Kota Jambi yang diajarkan dengan menggunakan media poster dibandingkan dengan siswa kelas VII yang diajarkan tanpa menggunakan media poster. Untuk menjawab hipotesis tersebut dapat diketahui dengan melihat nilai gain scores.

Tabel 13. Hasil Perhitungan Skor Kelas Kontrol dan Kelas Eksperimen

\begin{tabular}{llllll}
\hline \multicolumn{1}{c}{ Kelas } & Mean & $\begin{array}{c}\text { Peningkatan } \\
\text { skor }\end{array}$ & $\begin{array}{c}\text { Rerata } \\
\text { Gain Score }\end{array}$ & Kategori \\
\hline Pre-test kelas kontrol & 16,75 & 1,22 & $\cdot 0,147$ & Rendah \\
\hline Post-test kelas kontrol & 17,97 & & & Sedang \\
\hline Pre-test kelas eksperimen & 16,09 & 2,82 & 0,316 & \\
\hline Post-test kelas eksperimen & 18,91 & & & \\
\hline
\end{tabular}

Dari hasil perhitungan diperoleh peningkatan skor kelas kontrol sebesar 1,22 dan peningkatan skor kelas eksperimen sebesar 2,82. Hal tersebut menunjukkan bahwa hasil peningkatan skor kelas eksperimen lebih besar 
dibandingkan hasil peningkatan skor kelas kontrol. Dilihat dari perbedaan mean post-test kelas eksperimen lebih besar dari mean kelas kontrol yaitu 18,91>17,97. Selain itu, perbedaan rerata gain score antara kelas kontrol dan kelas eksperimen sebesar 0,147 dan 0,316. Tingkat perolehan gain score dikategorikan menjadi tiga kategori yaitu 0,7 $\leq$ $(<\mathrm{g}>)$ berarti nilai tersebut masuk dalam kategori tinggi ; $0,3 \leq(<\mathrm{g}>)<0,7$ berarti nilai tersebut masuk dalam kategori sedang; dan $(<\mathrm{g}\rangle)<0,3$ berarti nilai tersebut masuk dalam kategori rendah. Jadi, nilai gain score kelas kontrol sebesar 0,147 yang diartikan masuk dalam kategori rendah dan nilai gain score kelas eksperimen sebesar 0,316 yang diartikan masuk dalam kategori sedang.

Dari hasil tersebut dapat disimpulkan bahwa media poster lebih efektif dalam pembelajaran keterampilan berbicara Biografi siswa kelas VII SMP Negeri 18 Kota Jambi. Jadi, $\mathrm{H}_{\mathrm{o}}$ yang berbunyi Penggunaan media poster sama efektifnya untuk pembelajaran keterampilan berbicara Biografisiswa kelas VII SMP Negeri 18 Kota Jambiyang diajarkan dengan menggunakan media poster dibandingkan dengan siswa kelas VII yang diajarkan tanpa menggunakan media poster berhasil ditolak. Sehingga, $\mathrm{H}_{\mathrm{a}}$ yang berbunyi Penggunaan media poster lebih efektif untuk pembelajaran keterampilan berbicara Biografisiswa kelas VII SMP Negeri 18 Kota Jambiyang diajarkan dengan menggunakan media poster dibandingkan dengan siswa kelas VII yang diajar tanpa menggunakan media poster dapat diterima.

\section{Pembahasan}

Dalam penelitian ini, terdapat dua kelas yaitu kelas kontrol dan kelas eksperimen. Penentuan kelas ditentukan dengan teknik purposive sampling. Dari teknik purposive sampling yang telah dilakukan, menghasilkan kelas VII D dengan jumlah 32 siswa sebagai kelas kontrol dan kelas VII F dengan jumlah 32 siswa sebagai kelas eksperimen.

Permasalahan dalam penelitian ini berawal dari hipotesis: Terdapat perbedaan prestasi belajar keterampilan berbicara Biografi siswa kelas VII antara kelas yang diajarkan dengan menggunakan media slot board dengan kelas yang diajarkan tanpa menggunakan media slot board. Dari data yang diperoleh, dapat diketahui bahwa terdapat perbedaan pada prestasi belajar keterampilan berbicara bahas Prancis antara kelas kontrol dan kelas eksperimen. Hal tersebut terlihat dari uji hipotesis I yang menunjukkan bahwa nilai $t_{\text {hitung }}$ lebih besar dari nilai $t_{\text {tabel }}$ dengan taraf signifikansi $5 \%$. Perbedaan tersebut dapat dilihat dari uji-t post-test antar kelompok kontrol dan kelompok eksperimen yang menunjukkan bahwa $t_{\text {hitung }}>t_{\text {tabel. }}$.

Dari hasil perhitungan diperoleh $t_{\text {hitung }}$ sebesar 2,463 kemudian setelah dikonsultasikan dengan $t_{\text {tabel }}$ pada taraf signifikansi 5\% dan df 62 sebesar 1,999 sehingga thitung lebih besar dari tabel yaitu 2,463>1,999. Selain itu, terdapat juga perbedaan rata-rata skor post-test kelompok eksperimen lebih besar dari kelompok kontrol yaitu 18,91>17,97. Selanjutnya, peningkatan skor kelas eksperimen lebih besar dibandingkan kelas kontrol yaitu 2,82>1,22. Dari hasil tersebut dapat diartikan bahwa pemberian perlakuan yang berbeda pada kedua kelompok kelas menyebabkan adanya perbedaan pada hasil akhir (post-test) kedua kelas tersebut. Meningkatnya skor siswa pada kelas eksperimen ini dikarenakan oleh media yang digunakan yaitu dengan penggunaan media poster. Media ini merupakan salah satu media yang dapat membuat suasana belajar menjadi lebih menyenangkan sehingga siswa tertarik untuk belajar biografi. Dengan media ini, siswa terdorong untuk ikut berpartisipasi aktif dan tidak pasif di kelas tanpa takut atau malu untuk berbicara biografi.Penggunaan media Poster lebih efektif untuk pembelajaran keterampilan berbicara Biografi siswa kelas VII yang diajarkan menggunakan media Poster dibandingkan dengan siswa kelas VII yang diajarkan tanpa menggunakan media Poster.

Salah satu solusi untuk membuat pembelajaran biografi menjadi lebih menyenangkan adalah dengan menggunakan sebuah media yang dapat menarik siswa dalam mempelajari pelajaran biografi.

Pada pembelajaran keterampilan berbicara biografi, media poster merupakan media yang dimaksudkan untuk melatih kepercayaan diri pada siswa dalam berbicara didepan kelas tanpa rasa malu, takut melakukan kesalahan maupun ragu-ragu. Selain itu, media poster diharapkan mampu memberikan situasi yang menyenangkan tanpa rasa bosan dan serius di dalam lingkungan belajar. Media ini memberikan motivasi kepada siswa untuk berpartisipasi aktif dalam pembelajaran berbicara biografi.

Berdasarkan hasil penelitian, setelah dilakukan pre-test keterampilan berbicara Biografikelas kontrol dan kelas eksperimen menunjukkan bahwa prestasi kedua kelas tersebut sebanding atau tidak terdapat perbedaan yang signifikan. Setelah dilakukan post-test terdapat peningkatan skor yang berbeda antara kelas kontrol dan kelas eksperimen. Dari hasil perhitungan diperoleh peningkatan skor kelas kontrol sebesar 1,22 dan peningkatan skor kelas eksperimen sebesar 2,82. Hal tersebut berarti bahwa hasil peningkatan skor kelas eksperimen lebih besar dibandingkan hasil peningkatan skor kelas kontrol. Berdasarkan perbedaan dari mean post-test kelas kontrol dan kelas eksperimen, mean dari kelas eksperimen lebih besar dibandingkan mean kelas kontrol yaitu 18,91>17,97.

Selain itu, perbedaan rerata gain score antara kelas kontrol sebesar 0,147 dan kelas eksperimen sebesar 0,316. Rerata gain score kelas kontrol dikategorikan rendah dan kelas eksperimen dikategorikan sedang. Dengan demikian dapat disimpulkan bahwa penggunaan media poster lebih efektif untuk pembelajaran keterampilan berbicara Biografisiswa kelas VII SMP Negeri 18 Kota Jambi yang diajarkan menggunakan media poster dibandingkan dengan siswa kelas VII yang diajarkan tanpa menggunakan media poster. Keterbatasan Penelitian Dalam penelitian ini tidak 
terlepas dari beberapa keterbatasan. Adapun keterbatasan penelitian adalah sebagai berikut. Peneliti adalah seorang peneliti pemula sehingga baik dari pengalaman, teori maupun praktiknya di lapangan masih belum maksimal dan sangat terbatas. Peneliti hanya mengambil sampel di satu sekolah saja sehingga memungkinkan terjadinya interaksi antar siswa yang menyebabkan hasilnya masih mungkin terjadi pembiasan.

\section{SIMPULAN}

Dari hasil penelitian dan analisis yang telah disampaikan, maka dapat disimpulkan sebagai berikut:

1. Terdapat perbedaan prestasi belajar keterampilan berbicara Biografi antara siswa kelas VII SMP Negeri 18 Kota Jambi yang diajarkan dengan menggunakan media poster dengan siswa yang diajarkan tanpa menggunakan media poster. Keterampilan berbicara Biogra fisiswa yang diajarkan dengan menggunakan media poster ternyata lebih baik daripada yang diajarkan tanpa menggunakan media poster. Hal tersebut dapat diketahui dari hasil perhitungan uji-t dimana thitung >ttabel yaitu 2,463>1,999.

2. Penggunaan media poster lebih efektif untuk pembelajaran keterampilan berbicara Biografi siswa kelas VII F SMP Negeri 18 Kota Jambi yang diajarkan dengan menggunakan media poster dibandingkan dengan siswa kelas VII D yang diajar tanpa menggunakan media poster. Hal tersebut dapat diketahui dari hasil perhitungan rata-rata skor kelas kontrol dan kelas eksperimen. Pada kelas kontrol terdapat peningkatan sebesar 1,22 sedangkan pada kelas eksperimen terdapat peningkatan sebesar 2,81. Perbedaan tersebut juga terlihat dari perhitungan gain score. Jumlah rerata gain score kelas kontrol sebesar 0,147 dan kelas eksperimen sebesar 0,316. Sehingga, tingkat 73 perolehan gain score kelas kontrol dikategorikan rendah sedangkan kelas eksperimen dikategorikan sedang.

\section{DAFTAR PUSTAKA}

Alwi, Hasan, Soenjono Dardjowidjojo, Hans Lapoliwa dan Anton M. Moeliono. 2003. Tata Bahasa Baku Bahasa Indonesia. Jakarta: Balai Pustaka.

Arikunto, S. (2013). Prosedur Penelitian: Suatu Pendekatan Praktik. Jakarta: Rineka Cipta.

Arsyad, Azhar. 2002. Media Pembelajaran. Jakarta: PT Raja Grafindo Persada.

Arsyad, Azhar \& Maidar. G. 1988. Pembinaan Kemampuan Berbicara Bahasa Indonesia. Jakarta: Erlangga.

Daryanto. 2010. Media Pembelajaran. Yogyakarta: Gava Media.

$$
\text { 2011. Media Pembelajaran. Yogyakarta: Gava Media. }
$$

Depdiknas.1990. Kamus Besar Bahasa Indonesia. Jakarta: Gramedia

Dina Indriana.2011. Ragam Alat Bantu Media Pengajaran.Yogyakarta:Diva Press.

Hardjana. 2006. Cara Mudah Mengarang Cerita Anak-anak. Jakarta:Grasindo.

Hasan, M. Iqbal. 2002. Pokok-pokok Materi Metodologi Penelitian dan Aplikasinya. Jakarta: Ghalia Indonesia.

Hendrikus, Dori Wuwur. 2005. Retorika Terampil Berpidato, Berdiskusi, Berargumentasi, Bernegosiasi. Yogyakarta: Kanisius.

Liotohe, Wimanjaya K. 1991. Petunjuk Praktis Mengarang Cerita Anak-anak. Jakarta: Balai Pustaka.

Margono, S. 2005. Metodologi Penelitian Pendidikan. Jakarta: PT Rineke Cipta.

Martono, Nanang. 2012. Metode Penelitian Kuantitatif, Jakarta: PT Rajagrafindo Persada.

Nurgiyantoro, Burhan. 2001. Penilaian dalam Pengajaran Bahasadan Sastra. Yogyakarta: BPFE.

Nurgiyantoro, Burhan. 2005. Sastra Anak. Yogyakarta. Gajah Mada: University Press.

Nurgiyantoro, Burhan. 2009. Statistik Terapan untuk Penelitian Ilmu Sosial. Yogyakarta: Gajah Mada University Press.

Santoso,F.X.1982. Tujuh Persoalan Dasar Berbicara dalam Pendidikan dan Pengajaran. Bandung: CV. Remaja.

Sudibyo.1997. Pengembangan Keterampilan Berbicara. Jakarta. Departemen Pendidikan dan Kebudayaan.

Sugiyono. 2009. Metode Penelitian Kuantitatif Kualitatif dan R\&D. Bandung: Alfabeta. 